\author{
Sabina KAUF, Agnieszka TŁUCZAK \\ Opole University \\ Department of Logistics and Marketing \\ skauf@uni.opole.pl, atluczak@uni.opole.pl \\ Kateryna LYSENKO-RYBA \\ University of Information Technology and Management in Rzeszow \\ Chair of Logistics and Process Engineering \\ klysenko@wsiz.rzeszow.pl
}

\title{
THE EFFECTS OF PERCEIVED CSR AND ECOLOGICAL AWARENESS ON PURCHASE DECISIONS IN POLAND
}

\begin{abstract}
Corporate Social Responsibility (CSR) is a concept, that allows companies to manage their business including economic, ecological and ethical dimensions. It means that companies think about their employees, customers, stakeholders and environment. Doing business according to the concept of CSR can help companies to improve their "green" image. This article presents the idea of corporate social responsibility concept in Polish conditions. The study involved a group of 3,000 random respondents from two different geographical districts (voivodships): Opolskie (well developed) region and Podkarpackie (underdeveloped) region of Poland. The main objective of this study was to investigate how consumers in two economically diverse regions of Poland perceive the concepts of corporate social responsibility, and how that perception affects their purchasing decisions.
\end{abstract} ethics

Keywords: Corporate Social Responsibility, ecological awareness, business

\section{WPŁYW CSR ORAZ EKOLOGICZNEJ ŚWIADOMOŚCI KONSUMENTÓW NA DECYZJE ZAKUPOWE W POLSCE}

Streszczenie. Społeczna Odpowiedzialność Społeczna (CSR) to narzędzie, które pozwała firmom zarządzać swoją działalnością w wymiarze ekonomicznym, ekologicznym i etycznym. Oznacza to, że przedsiębiorstwa dbają o dobrobyt swoich pracowników, klientów, interesariuszy oraz środowisko. Prowadzenie działalności gospodarczej zgodnie $\mathrm{z}$ koncepcją CSR może pomóc firmom poprawić swój „,zielony” wizerunek. W artykule przedstawiono ideę koncepcji społecznej odpowiedzialności biznesu w polskich warunkach. W badaniu wzięło 
udział 3000 losowych respondentów z dwóch różnych okręgów geograficznych: województwa opolskiego (dobrze rozwiniętego) i Podkarpackiego (relatywnie słabo rozwiniętego). Głównym celem było zbadanie, w jaki sposób konsumenci w dwóch ekonomicznie zróżnicowanych regionach Polski postrzegają pojęcia odpowiedzialności społecznej przedsiębiorstw i jak ta percepcja wpływa na ich decyzje zakupowe.

Słowa kluczowe: Społeczna Odpowiedzialność Biznesu (CSR), świadomość ekologiczna, etyka w biznesie

\section{Introduction}

Consumers make a number of daily purchasing decisions when expending their financial resources. The socially conscious consumers also demonstrate their positive attitudes towards responsible purchasing behaviors by accepting that the price of goods and services must also reflect the cost of an environmental impact of related economic activities. This implies that modern consumption is not just an act of purchasing, but also an expression of the consumers' value system. Buying "green products", which are produced in accordance with the principle of "fair play", is a vote for the environment and support for the human rights worldwide. It also reflects consumers' acceptance of those companies that act according to the principles of social responsibility. According to the European Commission's Green Paper Corporate Social Responsibility (CSR) is a voluntary concept taking into account the social and environmental aspects in conducting commercial activities and in dealing with the environment ${ }^{1}$. It helps to improve competition in the fields of costs and financial performance. Also, CSR helps to increase the efficiency of using human potential. CSR is the engine of innovation, it facilitates risk management and most importantly improves the company's image in the eyes of customers ${ }^{2}$.

Enterprises which bet on the CSR not only increase the value of their business but also enhance competitive advantage, improve their financial condition, reduce the risk of bankruptcy and build good relationships with their customers. Social responsibility contributes to the buyers' confidence, that's why companies have a stable market position, positive image and satisfied employees.

Without active involvement in social activities - in the sense of the words and deeds companies may suffer negative consequences leading up to the loss of social acceptance (License to operate). That is why many traders implements the principles of social responsibility. For example, IKEA acquires $76 \%$ of cotton from sustainable sources and there

\footnotetext{
1 Green Paper. Promoting The European framework for the Corporate Social Responsibility, European Commision.

2 Communication from the commission on the European Competitiveness Report 2008-SEC (2008)2853, Brussels 2008.
} 
are over 700 thousand solar panels on its buildings across the world. Moreover, IKEA is committed to purchase and maintenance of 224 wind turbines.

The main objective of this study was to investigate how consumers in two economically diverse regions of Poland perceive the concepts of corporate social responsibility, and how that perception affects their purchasing decisions. Specifically, the following two research questions have been addressed:

Q1: What is the level of understanding of the concept of CSR by Polish consumers?

Q2: What are the main aspects of CSR that affect purchasing decisions by Polish consumers?

With respect to Q1, this study investigated how Polish consumers perceive the concept of CSR. Specifically, we tried to define respondents' understanding of the CSR concept. With respect to questions Q2, the following hypothesis were investigated to show which aspect economic, social or ecological most affect Polish customers during their purchases.

In order to test above stated objectives three research hypotheses related to public perception of CSR have been investigated:

H1: Consumer purchasing decisions are affected by economic aspects of CSR

H2: Consumer purchasing decisions are affected by social aspects of CSR

H3: Consumer purchasing decisions are affected by ecological aspects of CSR

Data about the knowledge of the ideas and principles of CSR were collected among the inhabitants of two economically different geographical districts (voivodships): Opolskie (well developed) region and Podkarpackie (underdeveloped) region of Poland. The average per capita income among respondents from the Opole voivodeship fluctuated around 1,150 PLN (287,5 USD) and in Podkarpackie - 940 PLN (235 USD). They differ among themselves not only in occupied earth surface and the absolute number of people but mainly in the geographical location of border, as well as penetrating the centuries, different cultures and traditions. Opole voivodship is characterized by the proximity to the western border and multi-annual, historical ties with the German neighbor, while Podkarpackie voivodship is located on the eastern border, adjacent to the Ukraine, and maintains long-standing relations with the countries of the east. These different cultural influences and international contacts may but do not have to affect consumer behavior and perception of contemporary reality. Data were collected by questionnaire, which firstly were conducted like the pilot studies in 2014 and then they have been verified and modified. It allowed for obtaining comprehensive information regarding the knowledge and recognition CSR by the inhabitants of these regions.

The study involved a group of 3,000 random respondents from the surveyed regions. This selection considering the size of the sample trial and the relative compatibility sample structures and the general population allows to make some generalizations. We used 2842 fully completed survey questionnaires for the analysis, which gave responsiveness rate of $95 \%$. Two questionnaires were not taking into consideration, because the respondents showed lack of knowledge of the concept of CSR. The tested sample consisted of $53 \%$ of women and 
47\% men, 1,589 respondents live in Opole voivodship, the other 1,253 people in Podkarpackie voivodship.

We used both forms of surveys, traditional - in the form of auditorium survey, which was handed out at conferences and seminars organized in the region of Opole and Podkarpackie and an online survey. We obtained $68 \%$ of completed questionnaires via Internet. On-line questionnaires were based on HTML language. The questionnaire was commonly available for all websites. The questionnaire consisted of 13 closed questions, using different scales to measure attitudes. We have used both a five-point Likert scale, as well as a cafeteria semiopen, leaving the respondent the opportunity to provide their own answers.

\section{Theoretical framework of CSR}

The concept of Corporate Social Responsibility (CSR) realizes that companies operate among a wide range of stakeholders and should conduct their business activities in order to meet the needs of each interest groups. However some scientists believe that this concept needs redefinition in order to provide a mutual benefit (shared value) to both the company and society $^{3}$. Davies said that social responsibility begins where the law ends ${ }^{4}$. This definition shows the true intentions which should be guided by the company acting in responsible way. Most generally CSR can be defined as the strategy of the organization based on a specific concept of the philosophical and normative functioning of the organization. It is a voluntary organization's commitment to conditional and unconditional obligations towards social opinions, ideas and expectations ${ }^{5}$. Socially responsible decisions can ensure achievement of multiple goals and long-run profit maximization ${ }^{6}$. Johnson asserted that social responsibility was necessary since firms needed to balance multiple interests (stockholders, employees, suppliers, dealers, and local communities) to ensure the achievement of multiple goals and long-run profit maximization. Stakeholders often expect companies to sponsor only those social issues that have a good fit, or a logical association, with their core corporate activities ${ }^{7}$. According to Visser the current concept of social responsibility doesn't work (but it brings some positive effects), because the changes that are introduced on the basis thereof, are

\footnotetext{
${ }^{3}$ Porter M.E., Kramer M.R.: The big idea: Creating shared value. "Harvard Business Review”, 2011.

${ }^{4}$ Davis K.: Can Business Afford to Ignore Social Responsibilities? "California Management Review”, No. 2, 1960.

5 Teraji S.: A model of corporate social performance: Social satisfaction and moral conduct. „The Journal of Socio-Economics", No. 38, 2009.

${ }^{6}$ Johnson H.L.: Business in Contemporary Society: Framework and Issues. Wadsworth, Belmont, CA 1971.

7 Haley E.: Exploring the construct of organizations as source: consumers' understanding of organizational sponsorship of advocacy advertising. "Journal of Advertising”, No. 25, 1996.
} 
secondary, uneconomical and implemented on a small scale ${ }^{8}$. For Caroll CSR includes economic, legal, ethical, and discretionary expectations of society 9 :

1. Economic dimension is assumed that the corporation is an instrument for wealth creation and that this is its sole social responsibility. So any supposed social activity is accepted only in the situation, where the wealth value is added ${ }^{10}$.

2. Legal responsibilities refer to fulfilling the economic responsibility within the boundaries set by the legal system of the country. This may include compliance with various legal requirements including workers safety, environmental standards and tax laws ${ }^{11}$.

3. Ethical dimension means that the relationship between company and society is connected with ethical values. Ethical responsibility are to do what is right and useful for nature and people. Ethics takes responsibility to another level in that compliance goes beyond the legal requirements.

According to Kashyap, Mir R. and Mir A. economic and legal obligations refer to (clearcut) mandated responsibilities while ethical and discretionary obligations refer to (not so clear-cut) societal expectations ${ }^{12}$. Caroll added another dimension and defined it as philanthropic activity ${ }^{13}$. According to Crane and Matten CSR has three considerations economic, social and environmental. The last aspect means that company tries to manage the resources effectively in order to leave a decent conditions for future generations ${ }^{14}$.

Over the years, the customer's attributions for CSR has been widely discussed in the literature. Consumers attribute multiple and specific corporate motives to CSR, for example actions which include strategic-driven when concerns want to increase sales or avoid harm, stake-holder driven, when companies act because of stakeholders pressure, and value-driven motives, when firms believe that CSR should be taken into account in their business ${ }^{15}$.

Ramasamy and Yeung in their study compared Chinese consumers' perception of CSR in Shanghai and Hong Kong and results of similar studies conducted in Europe and the USA ${ }^{16}$. The result is that Chinese consumers are more supportive to CSR. Maignan conducted a consumer survey in France, Germany and the USA. Study has shown that all these countries

\footnotetext{
${ }^{8}$ Visser W.: The Age of Responsibility: CSR 2.0 and the New DNA of Business. Wiley, London 2011.

9 Carroll A.B.: A Three-Dimensional Conceptual Model of Corporate Social Performance. „Academy of Management Review“, No. 4(4), 1979.

${ }^{10}$ Garriga E., Mele D.: Corporate Social Responsibility Theories: Mapping the Territory. "Journal of Business Ethics", No. 53, 2004.

11 Ramasamy B., Yeung M.: Chinese Consumers' Perception of Social Responsibility (CSR). "Journal of Business Ethics", No. 88, 2009.

${ }^{12}$ Kashyap Mir R., Mir A.: Corporate Social Responsibility: A Call For Multidisciplinary Inquiry. "Journal of Business \& Economics Research”, Vol. 2, No. 7, 2011.

${ }^{13}$ Carroll A.B.: op.cit.

${ }^{14}$ Crane A., Matten D.: Business ethics: Managing corporate citizenships and sustainability in the age of globalization. 2007.

15 Ellen P.S., Webb D.J., Mohr L.A.: Building Corporate Associations: Consumer Attributions for Corporate Socially Responsible Programs. "Journal of the Academy of Marketing Science”, No. 34(2), 2006.

${ }^{16}$ Ramasamy B., Yeung M.: op.cit.
} 
have different perception of CSR - European consumers are mostly concerned about business conforming with legal and ethical standards, whereas American consumers value economic responsibility ${ }^{17}$. Research about Polish consumer's perception of CSR was made in 2011 by the Research Laboratory of Social Communication. The sample was consist of 1000 respondents. The main topic of the research was the impact of actions in the field of CSR undertaken by the brand in the consumer choices. This studies have shown that CSR has a large influence on the purchasing decisions of Polish consumers. Due to the respondents the term CSR is usually interpreted as:

- company's responsibility - in a very wide sense: the responsibility for decisions making, fulfillment of obligations, bearing the consequences of decisions;

- fairness - acting with the principles of fairness with business partners, customers and employees;

- $\quad$ supporting the weak - charity work, helping the poor people.

Less frequently respondents associated CSR with actions for environment, employees and the specific characteristics of the product such as quality (using an ecological ingredients). We think that this issues are so topical and important that it should be regularly evaluated.

Table 1

Profile of samples

\begin{tabular}{|l|l|c|c|}
\hline \multicolumn{2}{|c|}{} & $\begin{array}{c}\text { Opolskie } \\
\mathbf{N = 1 5 8 9}\end{array}$ & $\begin{array}{c}\text { Podkarpackie } \\
\mathbf{N}=\mathbf{1 2 5 3}\end{array}$ \\
\hline \multirow{2}{*}{ Gender } & Male & 747 & 589 \\
\cline { 2 - 4 } & Female & 842 & 664 \\
\hline \multirow{3}{*}{ Age } & Min & 20 & 21 \\
\cline { 2 - 4 } & Mean & 48 & 34 \\
\cline { 2 - 4 } & Max & 61 & 47 \\
\hline \multirow{3}{*}{ Income } & Mean & 1150 & 940 \\
\cline { 2 - 4 } & Less than 500 PLN for person & $16 \%$ & $35 \%$ \\
\cline { 2 - 4 } & Above 2000 PLN for person & $24 \%$ & $17 \%$ \\
\hline
\end{tabular}

Source: Own.

\section{Results of analysis}

\subsection{Respondents' understanding of the CSR concept}

The main objective of this part is the identification of the CSR perception by Polish consumers. The contemporary economic situation forced the increased interest in the idea of socially responsible activities. Today, companies participate more actively in social life and exert an influence on society. This phenomenon intensified by the dynamics of communication processes related to the development of the Internet and social networking sites. The customers

\footnotetext{
${ }^{17}$ Maignan I.: Consumers' Perception of Corporate Social Responsibility: A Cross Cultural Perception. "Journal of Business Ethics", No. 30(1), 2001.
} 
can exchange information there not only about product quality, but also about their points of view of the producer. Thus, for example, information about the brutal capitalist methods of the large companies will have an impact on corporate image and brand. Public opinion is increasingly interested in the behavior of companies, their ways of treatment of employees, the degree of commitment to environmental protection, participation in corrupt practices, etc.

The CSR concept has many aspects. Implementation of the concept takes place on many levels. However, respondents understand by CSR mainly social activities undertaken by businesses (Table 2). Among several possibilities that answer was considered the most important.

Table 2

Respondents' understanding of the CSR concept

\begin{tabular}{|l|c|}
\hline Understanding of CSR term & \% of respondent \\
\hline Taking into account sustainable development principles (H3 ecological) & 25 \\
\hline Making profit according to the legal regulations (H1 economic) & 21 \\
\hline $\begin{array}{l}\text { Undertaking by enterprises the economic activities, which take into account the social } \\
\text { aspect (H2 social) }\end{array}$ & 54 \\
\hline
\end{tabular}

Source: Own.

Table 3

The results of logistic regression

\begin{tabular}{|l|c|c|c|c|}
\hline & Constant & X1 & X2 & X3 \\
\hline Estimation & -0.842 & 1.347 & 0.948 & 0.654 \\
\hline The standard error & 0.246 & 0.049 & 0.019 & 0.024 \\
\hline $\mathrm{t}(2837)$ & -3.42 & 27.49 & 49.89 & 27.25 \\
\hline $\mathrm{p}$ value & 0.114 & 0.081 & 0.069 & 0.284 \\
\hline$-95 \%$ CL & -1.118 & -0.296 & -0.088 & -0.776 \\
\hline$+95 \%$ CL & 0.262 & 0.843 & 1.053 & 0.364 \\
\hline Wald Chi-square & 1.498 & 0.899 & 2.782 & 0.507 \\
\hline p value & 0.014 & 0.033 & 0.027 & 0.034 \\
\hline odds ratio & 0.652 & 1.315 & 1.620 & 0.814 \\
\hline$-95 \%$ CL & 0.327 & 0.744 & 0.916 & 0.460 \\
\hline$+95 \%$ CL & 1.299 & 2.323 & 2.867 & 1.439 \\
\hline odds ratio range & & 1.315 & 1.620 & 0.814 \\
\hline$-95 \%$ CL & & 0.744 & 0.916 & 0.460 \\
\hline$+95 \%$ CL & & 2.323 & 2.867 & 1.439 \\
\hline
\end{tabular}

Source: Own.

Because the implementation of social action can be done in several ways using logistic regression, it was determined which "way" was the most important in the eyes of respondents. The dependent variable was the understanding of the concept of CSR as taken by businesses of economic activities which take into account the ethical aspect. Whereas the independent variables are:

- $\mathrm{x}_{1}$ - economic aspect,

- $\mathrm{x}_{2}$ - social aspect,

- $\mathrm{x}_{3}$ - ecological aspect.

Received results allow to conclude that all methods have a positive impact ceteris paribus on the dependent variable. An economic aspect has the biggest importance in context of CSR, 
whereas the smallest aspect belongs to ecological one. The whole model was considered to be important because the value of the $p$ statistic $(\mathrm{p}<0.05)$. The perception of CSR as social actions taken by the company is independent on the region from which comes the respondent.

Table 4

ANOVA results for the recognition of CSR depending on the place of residence - voivodship

\begin{tabular}{|c|c|c|c|c|c|c|c|}
\hline SS effect & df effect & MS effect & SS error & df error & MS error & F & p \\
\hline 13.131 & 1 & 13.131 & 875.843 & 2480 & 0.308 & 42.633 & 0.000 \\
\hline
\end{tabular}

Source: Own.

\subsection{Source of information}

Information about CSR reaches respondents from various sources, but the quality of information is always different. The majority of information regarding CSR was obtained by respondents from the Internet and only after from the TV and radio. The lowest quality of the information assigned to those sources that came from the third parties. Current place of residence was the differentiating factor of respondents. Much more often the villagers heard about CSR from the third parties (27\% of respondents).

Table 5

Source and quality of information about CSR

\begin{tabular}{|l|c|c|}
\hline \multicolumn{1}{|c|}{ Source } & Quality of information & Number of respondents \\
\hline press & 2.9 & 875 \\
\hline Interent & 3.7 & 679 \\
\hline radio, TV & 3.0 & 543 \\
\hline third party & 2.2 & 745 \\
\hline
\end{tabular}

Source: Own.

Table 6

The differences in the evaluation of information quality about CSR submitted in different media due to the respondents' place of residence

\begin{tabular}{|l|c|}
\hline Source & p-value \\
\hline press & 0.000 \\
\hline Interent & 0.000 \\
\hline radio, TV & 0.000 \\
\hline third party & 0.178 \\
\hline
\end{tabular}

Source: Own.

Respondents rated highest the Internet, as a source of information about the principles of socially responsible business. Based on using the test of significance for two medium, it can be mentioned that in assessing the various sources of information about CSR, the differentiation occurs depending on the dimensions of their place of residence (table 6). In other cases there is no significant difference in the evaluation of these sources. The respondents clearly stated that information they got about the type and character of activities carried out by business in the field of CSR contributes to increase of their knowledge about CSR. Honest and reliable information may broad consumers interest in the idea of CSR and influence their purchasing decisions. 


\subsection{Respondent's income and its knowledge about CSR}

For a large part of society the recent financial crisis and the growing number of economical scandals confirm the conflict between economic and social interests. For economic world it means a decrease of acceptance and legitimacy for action. Without support from society neither market economy nor entrepreneurship cannot survive. Those entities, that do not take the social pressure seriously, can reduce their chances of long-term development. Therefore, the business world is looking for the possibility of guaranteeing public trust by promoting socially responsible activities and active information about them.

According to the data presented in Table 7, respondents have demonstrated an average knowledge of CSR. The primary activities in this area include the ethical behavior of companies and ethical attitudes of managers. These reviews do not depend on place of residence (the province from which the respondent comes from), which confirm the low values of p-value obtained in the analysis ANOVA (table 7).

Table 7

Differences in the understanding of the concept of CSR among respondents

by the place of residence

\begin{tabular}{|c|c|c|c|}
\hline & Opolskie & Podkarpackie & p-value \\
\hline Direct connection between business and ethics & $17 \%$ & $7 \%$ & 0.028 \\
\hline $\begin{array}{l}\text { This occurs when companies by taking some business decisions } \\
\text { take into account the ethical aspects of these decisions }\end{array}$ & $45 \%$ & $51 \%$ & 0.001 \\
\hline $\begin{array}{l}\text { The attitude of business people, decision making, choosing route } \\
\text { of action, the subject of teaching }\end{array}$ & $38 \%$ & $42 \%$ & 0.000 \\
\hline
\end{tabular}

Source: Own.

Table 8

Determination of statistical relationship between the cause application of the CSR principles by businesses and income of respondents

\begin{tabular}{|l|l|}
\hline \multicolumn{2}{|c|}{$\chi^{2}=\mathbf{3 0 1 2 . 1 5}>\chi^{2}{ }_{\alpha}=\mathbf{2 9 6 6 . 1 1 4} ; \boldsymbol{\alpha}=\mathbf{0 . 0 5}$} \\
\hline T Chuprov's coefficient & 0.32 \\
\hline Pearson's contingency coefficient & $0.71 \mathrm{tt}$ \\
\hline Adjusted Pearson's contingency coefficient & 0.88 \\
\hline
\end{tabular}

Source: Own.

Using the test of independence $\chi 2$ the statistical relationship between income of the respondents and the use of CSR as a tool to improve the image of the company was determined. Tested dependence is high, it means that with the increase of income of the respondent its belief grows in the positive impact of the application of CSR activities to improve the company's image. In this context it is no surprise that the experts of management are convinced that a responsible approach to doing business can be a source of improving their image Therefore, companies do not want to become acquainted with the principles of responsible business as long as they achieve their own benefits. In this case, CSR is a selfrealizing idea, which helps companies to combine classic marketing with environmental 
goals. According to the respondents, CSR can be an instrument to improve the image of the company among stakeholders ${ }^{18}$.

CSR is not always compatible with market success, and firms are increasingly expected to forego the benefits for the public welfare. The perception of economic entities often determines the belief that modern companies are increasingly ignoring the social costs and benefits to achieve their own economic goals. For some people this way of thinking is unacceptable from a moral and social point of view. More and more consumers while shopping are guided by the principle of selecting companies that declare themselves as socially responsible ${ }^{19}$.

Modern consumption is not only an act of purchase, but it also becomes an instrument to express the customer's beliefs or values. The importance of social attitudes of companies for their image perception by customers has a rich empirical tradition. It is known that highlighting the features of the company, such as social commitment helps to:

- stimulate a positive attitude to the company ${ }^{20}$,

- minimize the reputation damage,

- protect against the harmful effects of possible crisis situations ${ }^{21}$.

$48 \%$ of respondents admitted that sometimes they draw their attention to the fact that the good were produced by a company operating in accordance with the principles of CSR. Only $5 \%$ of respondents admitted, that they choose only those products.

Table 9

Determination of statistical relationship between CSR aspects taking into account in making purchasing decisions and consumer income

\begin{tabular}{|c|c|}
\hline \multicolumn{2}{|c|}{$\chi^{2}=3781.15>\chi_{\alpha}^{2}=2966.114 ; \alpha=0.05$} \\
\hline T Chuprov's coefficient & 0.36 \\
\hline Pearson's contingency coefficient & 0.76 \\
\hline Adjusted Pearson's contingency coefficient & 0.93 \\
\hline
\end{tabular}

Source: Own.

The relationship between income and the choice of goods, produced by a company operating in accordance with the principles of CSR is significant (Tab. 9), similarly as the relationship between income and the reason for application of the principles of CSR. In this context we state, that the ,richer” customer is more aware, has more time and especially money to buy goods produced in accordance with the principles of CSR. In Poland the reality is that products produced in compliance with CSR principles are more expensive. More customers are aware of the need to implement CSR principles and what is more important,

18 Maheshwari V. Kumar: To create a positive brand image through Corporate Social Responsibility. 2013, http://papers.ssrn.com/sol3/papers.cfm?abstract_id=2466844.

${ }^{19}$ Mohr L.A., Harris K.E.: Do consumers expect companies be socially responsible? The impact of corporate social responsibility on buying behaviors. „The Journal of Consumers Affairs”, Vol. 35, No. 1, 2001.

${ }^{20}$ Lichtenstein D.R., Drumwright M.E., Braig B.M.: The Effect of Corporate Social Responsibility on Customer Donations to Corporate-Supported Nonprofits. "Journal of Marketing", No. 68, 2004.

${ }^{21}$ Klein J., Dawar N.: Corporate Social Responsibility and Consumers' Attributions and Brand Evaluations in a Product-harm Crisis. „International Journal of Research in Marketing”, Vol. 21/3, 2004. 
they are willing to treat them, as a factor in their purchasing decisions. Therefore it can be considered that CSR, despite the fact that it requires enterprises to make larger financial investments, in the long term it will have a positively effect on generated profits. The ability to maintain a balance between the scope of CSR operations and generating profits is the new economic challenge for enterprises ${ }^{22}$.

\subsection{The influence of the ecological actions in the framework of CSR}

The aim of modern "eco-consumerism" is to transform the current model of consumption into the sustainable consumption. It is extremely important for future generations to realize the ecological aspect. It can be reflected by making informed purchase decisions by consumers' selection the products the manufacture of which were implemented "green" principles of CSR. These principles in the field of ecology should be well known to consumers. Consumers with a high degree of environmental awareness will take action to protect the environment by buying eco-products, avoiding product packaging which is not biodegradable, segregating waste and supporting organizations and movements of "green". In response to the needs and preferences of "green" buyers, companies expand their market offer, introducing new product categories, eg. P\&G introduced in Europe detergents to be used in cold water - Ariel Cool Clean, Clorox Company launched natural and synthetic cleansers Green Works and biodegradable wipes, etc.

According to the respondents the fact that the company respects the ecological aspects of CSR is an important factor in deciding to purchase a product. The respondents of both regions agree with this statement. The support for this view is dependent on the income of consumers. Definitely more often respondents with income above the average level for the studied regions pay attention to the environmental aspects of production (Table 10).

Table 10

The influence of the ecological actions in the framework of CSR undertaken by the company on the purchasing decisions of the respondents by place of residence and income

\begin{tabular}{|l|c|c|}
\hline & The value of the test statistics & p-value \\
\hline Place of residence & 0.015 & $<0.05$ \\
\hline Income & 3.158 & $>0.05$ \\
\hline
\end{tabular}

Source: Own.

The hypothesis related the influence of the place of origin on purchase decisions has been tested. P-value shows that the place of origin plays a role in choosing green products by respondents.

Whereas other respects as: biodegradable packaging, environmental protection and support for the ecological activities are not influenced by place of respondents' residence $(\mathrm{p}<0.05)$.

\footnotetext{
${ }^{22}$ Aupperle K., Carroll A., Hatfield J.: An empirical examination of the relationship between corporate social responsability and profitability. "Academy of Management Journal", (pre-1986); Jun 1985; 28, 000002; ABI/INFORM Global.
} 
Table 11

ANOVA results for particular environmental aspects taken into account the respondents by place of residence

\begin{tabular}{|l|c|c|c|c|c|c|c|c|}
\hline & $\begin{array}{c}\text { SS } \\
\text { effect }\end{array}$ & df & $\begin{array}{c}\text { MS } \\
\text { effect }\end{array}$ & $\begin{array}{c}\text { SS } \\
\text { error }\end{array}$ & $\begin{array}{c}\text { df } \\
\text { error }\end{array}$ & $\begin{array}{c}\text { MS } \\
\text { error }\end{array}$ & F & p \\
\hline $\begin{array}{l}\text { environmental } \\
\text { protection }\end{array}$ & 51.26 & 1 & 51.26 & 2824.98 & 2480 & 1.139 & 45.004 & 0.087 \\
\hline eco-labeling & 267.95 & 1 & 267.95 & 3219.51 & 2480 & 1.298 & 206.432 & 0.000 \\
\hline $\begin{array}{l}\text { biodegradable } \\
\text { packaging }\end{array}$ & 46.250 & 1 & 46.25 & 3145.21 & 2480 & 1.268 & 36.474 & 0.172 \\
\hline $\begin{array}{l}\text { support for the } \\
\text { ecological activities }\end{array}$ & 68.264 & 1 & 68.264 & 6412.97 & 2480 & 2.585 & 26.407 & 0.094 \\
\hline
\end{tabular}

Source: Own.

Based on theoretically supported linkages, we have developed and tested the model presented in Figure 1.

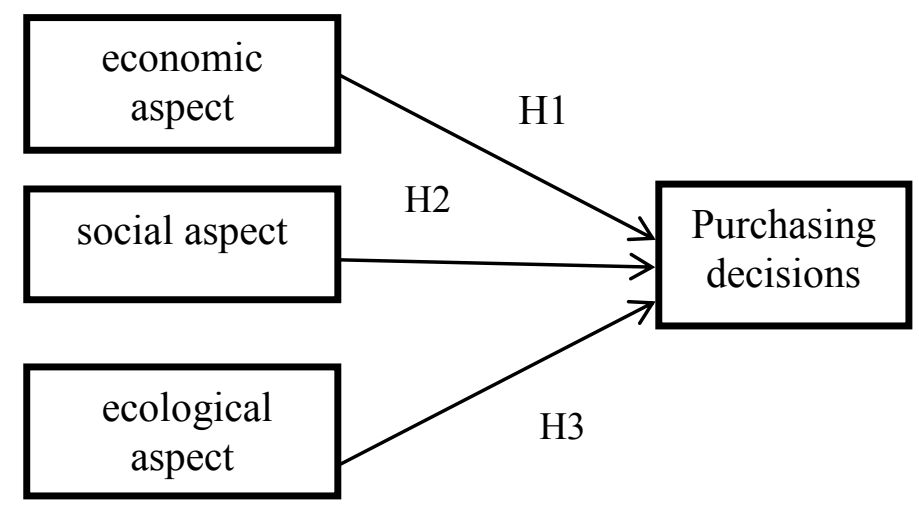

Fig. 1. The conceptual model

Source: Own.

Table 12 shows which module corresponds to which hypothesis. Questions from the survey have been divided according to the modules, column 3 presents the scope of assessment that appeared in the answers. Column 4 shows the average value and the last column presents the $\alpha$-cronbach's coefficient.

Table 12

Modules of the model

\begin{tabular}{|c|c|l|c|c|c|}
\hline $\begin{array}{c}\text { CSR } \\
\text { module }\end{array}$ & $\begin{array}{c}\text { Variable } \\
\text { number/ } \\
\text { qustion }\end{array}$ & \multicolumn{1}{|c|}{ Questions } & Range & Mean & $\boldsymbol{\alpha}$ \\
\hline \multirow{3}{*}{$\begin{array}{c}\text { Economic } \\
\text { (H1) }\end{array}$} & $\mathrm{x}_{1}$ & employment & $1-7$ & 3.42 & \\
\cline { 2 - 5 } & $\mathrm{x}_{2}$ & profit achieved in fair way & $1-6$ & 2.49 & \\
\cline { 2 - 5 } & $\mathrm{x}_{3}$ & promotion item & $2-7$ & 3.78 & \multirow{2}{*}{0.72} \\
\cline { 2 - 5 } & $\mathrm{x}_{4}$ & $\begin{array}{l}\text { contribution to the development of the economy } \\
\text { by investing and paying taxes }\end{array}$ & $1-7$ & 2.19 & \\
\cline { 2 - 5 } & $\mathrm{x}_{5}$ & quality products at the right prices & $2-7$ & 3.01 & \\
\hline
\end{tabular}


cont. table 12

\begin{tabular}{|l|l|l|c|c|c|}
\hline \multirow{4}{*}{$\begin{array}{l}\text { Social } \\
\text { (H2) }\end{array}$} & $\mathbf{x}_{6}$ & social participation and charitable giving & $3-6$ & 3.84 \\
\cline { 2 - 5 } & $\mathrm{x}_{7}$ & protection of human rights & $1-7$ & 2.73 \\
\cline { 2 - 5 } & $\mathrm{x}_{8}$ & care for the safety & $1-6$ & 3.16 \\
\cline { 2 - 5 } & $\mathrm{x}_{9}$ & avoiding corruption and bribery & $2-6$ & 3.42 \\
\cline { 2 - 5 } & $\mathrm{x}_{10}$ & sensitivity to the social needs & $1-7$ & 3.94 \\
\hline \multirow{4}{*}{$\begin{array}{l}\text { Ecological } \\
\text { (H3) }\end{array}$} & $\mathrm{x}_{11}$ & protection of the natural environment & $1-7$ & 3.27 \\
\cline { 2 - 5 } & $\mathrm{x}_{12}$ & eco-labeling & $1-7$ & 3.19 \\
\cline { 2 - 5 } & $\mathrm{x}_{13}$ & biodegradable packaging & $2-7$ & 3.57 \\
\cline { 2 - 5 } & $\mathrm{x}_{14}$ & supporting the environmental actions & $1-7$ & 2.14 & \\
\hline
\end{tabular}

Source: Own.

Our research shows that all hypotheses have been verified positively on the significance level of $5 \%$. It means that the identified dimensions of corporate social responsibility influence inhabitants' purchasing decisions. It was investigated which factor is the most important separately for each module. For the economic module the most important is quality products at the right prices, for social aspect - social participation, charitable giving and avoiding corruption and bribery, for ecological module - eco-labeling.

These findings confirm the results obtained in the application of logistic regression (table 13-15) due to the p-value models proved to be well matched and the parameters were significantly different from zero.

Table 13

The results of the logistic regression of the model estimation - economic module

\begin{tabular}{|l|c|c|c|c|c|c|}
\hline & Constant & $\mathbf{X}_{\mathbf{1}}$ & $\mathbf{X}_{\mathbf{2}}$ & $\mathbf{X}_{\mathbf{3}}$ & $\mathbf{X}_{\mathbf{4}}$ & $\mathbf{X}_{\mathbf{5}}$ \\
\hline Estimation & 0.245 & 1.254 & 2.160 & 1.457 & 2.943 & 3.267 \\
\hline The standard error & 0.214 & 0.045 & 0.327 & 0.086 & 0.145 & 0.841 \\
\hline $\mathrm{t}(2837)$ & 1.145 & 27.867 & 6.606 & 16.942 & 20.297 & 3.885 \\
\hline $\mathrm{p}$ value & 0.091 & 0.139 & 0.074 & 0.0826 & 0.271 & 0.425 \\
\hline
\end{tabular}

Source: Own.

In case of the impact of economic factors on the CSR purchasing decisions seem to have been justification in classical economics, appealing to rational decision-making based on maximizing the utility function. Hence there is a big influence of product quality and adequate prices in the decision-making process. The rationalization of decisions of Polish consumers may result from the fact of their insufficient (subjectively perceived) purchasing power, which does not allow them to make choices that do not include aspects of money.

However, any consumer is not fully rational during his decision making under the influence of emotions or other external factors. Therefore, such issue as contribution to the development of the economy by investing and paying taxes is very important for Polish consumers. So important impact of this factor may result from consumers' desires to protect the economy of the domestic market. In this context, the surprise may be the smallest importance of employment and its protection in the process of making purchase decisions. Supporting the economy and investment is closely connected with the protection of domestic business and the maintaining of current workplaces. As a result - the financial stability of residents. 
Table 14

The results of the logistic regression of the model estimation - social module

\begin{tabular}{|l|c|c|c|c|c|c|}
\hline & Constant & $\mathbf{X}_{\mathbf{6}}$ & $\mathbf{X}_{\mathbf{7}}$ & $\mathbf{X}_{\mathbf{8}}$ & $\mathbf{X}_{\mathbf{9}}$ & $\mathbf{X}_{\mathbf{1 0}}$ \\
\hline Estimation & -0.451 & 2.341 & 0.974 & 0.378 & 2.347 & 1.164 \\
\hline The standard error & 0.153 & 0.034 & 0.742 & 0.254 & 0.129 & 0.067 \\
\hline $\mathrm{t}(2837)$ & -2.948 & 68.853 & 1.313 & 1.488 & 18.194 & 17.373 \\
\hline $\mathrm{p}$ value & 0.098 & 0.194 & 0.241 & 0.272 & 0.294 & 0.067 \\
\hline
\end{tabular}

Source: Own.

Analyzing the impact of the social aspects of CSR on the purchasing decisions of Polish consumers it should be noted that the most important role is played by such aspects as social participation, charitable giving and avoiding corruption and bribery. A significant impact of the manufacturers' charity on the buyers' purchasing decisions may be a consequence of the growing importance of consumption as a mean of emphasizing social status. Consumers are sensitive of the demonstration effect, which allows them to feel as a part of a particular group of reference. On the other hand, it allows consumers to show themselves as socially responsible individuals. In addition, the charities are often part of promotional campaigns, and consumers increasingly recognize the positive impact of donations and social support of producers on the situation of the poorest. Taking into account the charity in purchasing decisions it appears to stem from an increase of the maturity of Polish society, which as it becomes more and more socially responsible, and somehow forces producers operating in the domestic market to get more involved in charity.

In contrast, the relatively large impact of avoiding corruption and bribery on purchase decisions may be a consequence of the negative experience, Polish consumers learned from a bygone era. It was the actions of corruption. It can be assumed that the unethical practices of producers significantly discourage consumers from purchasing their products.

Table 15

The results of the logistic regression of the model estimation - ecological module

\begin{tabular}{|l|c|c|c|c|c|}
\hline & Constant & $\mathbf{X}_{\mathbf{1 1}}$ & $\mathbf{X}_{\mathbf{1 2}}$ & $\mathbf{X}_{\mathbf{1 3}}$ & $\mathbf{X}_{\mathbf{1 4}}$ \\
\hline Estimation & 0,341 & 1,024 & 2,428 & 0,941 & 0,719 \\
\hline The standard error & 0,041 & 0,243 & 0,429 & 0,064 & 0,048 \\
\hline $\mathrm{t}(2837)$ & 8,317 & 4,214 & 5,660 & 14,703 & 14,979 \\
\hline $\mathrm{p}$ value & 0.061 & 0.107 & 0.305 & 0.146 & 0.217 \\
\hline
\end{tabular}

Source: Own.

We can observe a trend of increasing the level of environmental awareness and the growing prestige of being a consumer-friendly environment in Poland. This means that consumers increasingly take into account the environmental aspects in their purchasing decisions. Sometimes we can say that an eco-friendly consumer is being formed in Poland, looking for environmentally friendly products and willing to pay for them a slightly higher price. Very often Polish consumers buy products with labels, which clearly show that they are organic. 
This applies not only to the product components, but also to the packaging. Reusable packaging of products are mostly preferred, because of the clear evidence of their ecological origin. Therefore, a biodegradable products and packaging are very important during the purchasing decisions. Despite the consideration of environmental aspects in purchasing decisions of Polish consumers, their ecological awareness seems to be still lower than in other European countries. Conscious consumption is very difficult and expensive, that is why many Polish consumers simply cannot afford to make the purchase of products manufactured with the concept of social responsibility. We can positively evaluate obtained results which confirm the growing awareness of consumers.

\section{Summary}

Corporate social responsibility is a concept, that allows companies to manage their business in a way where wider interests of the social environment are taking into account. Companies are expected not only to increase profit margins but also to think about the environment and workers. Social involvement is currently, out of charity, answering to the needs of the community. The most important is the fact, that companies have implemented processes by which social, environmental, ethical considerations and human rights issues would become a regular part of their business and business strategy. Doing business according to the concept of CSR is considered, as part of a promotion, that will help to improve the company's image. From the point of view of promoting and implementing responsible business principles it is necessary to educate the public, the managers and the employees of the companies. Issues related to ethical business context should be included to the study programs and various training courses.

According to our survey research we have received the following results:

- The concept of CSR is mainly associated with decision making that follows social principles (H2). Respondents understand by CSR mainly social activities undertaken by businesses. $54 \%$ of respondents associate CSR with undertaking by enterprises the economic activities, which take into account the social aspect;

- Promotion of CSR ideas by mass media translated into increasing of consumer awareness in terms of CSR. The majority of information regarding CSR was obtained by respondents from the Internet and only after from the TV and radio. The respondents clearly stated that information they got about the type and character of activities carried out by business in the field of CSR contributes to increase of their knowledge about CSR. Honest and reliable information may broad consumers interest in the idea of CSR and influence their purchasing decisions; 
- Higher personal income effects consumer's perceptions of positive impact of CSR (H1). In this context we state, that the ,richer" customer is more aware, has more time and especially money to buy goods produced in accordance with the principles of CSR. Definitely, more often respondents with income above the average level for the studied regions pay attention to the environmental aspects of production;

- Consumers do not consider CSR when making purchase decisions. 48\% of respondents admitted that sometimes they draw their attention to the fact that the good was produced by a company operating in accordance with the principles of CSR. Only $5 \%$ of respondents admitted, that they choose only those products;

- Consumers ecological awareness translates into making their purchase decisions (H3). Consumers with a high degree of environmental awareness take action to protect the environment. The support for this view is dependent on the income of consumers. Definitely more often respondents with income above the average level for the studied regions pay attention to the environmental aspects of production.

The results of this study is important not only to Polish business as they struggle with CSR as the strategic component of their business, but also for foreign companies when they decide to invest some capital into Polish market.

\section{Bibliography}

1. Aupperle K., Carroll A., Hatfield J.: An empirical examination of the relationship between corporate social responsability and profitability. "Academy of Management Journal" (pre1986); Jun 1985; 28, 000002; ABI/INFORM Global.

2. Barth R., Wolff F.: Corporate Social Responsibility in Europe. Rhetoric and Realities. Cheltenham 2009.

3. Bruhn M.: Begriffsabgrenzungen und Erscheinungsformen von Marken. Gabler Verlag, Bern-Stuttgart-Wien 2004.

4. Bustamante S.: CSR, Trust and the Employer Brand, CSR Trends. Beyond Business as Usual. Reichel J. (ed.), 2014, Chapter 4. CSR Impact, Łódź, Poland, 2014.

5. Carroll A.B.: A Three-Dimensional Conceptual Model of Corporate Social Performance. „Academy of Management Review“, No. 4(4), 1979.

6. Communication from the commission on the European Competitiveness Report 2008-SEC (2008)2853, Brussels 2008.

7. Crane A., Matten D.: Business ethics: Managing corporate citizenships and sustainability in the age of globalization. 2007.

8. Dahlsrud A.: How Corporate Social Responsibility is Defined: an Analysis of 37 Definitions, Corporate Social Responsibility and Environmental Management, effect of 
service quality. "Journal of Business Ethics", No. 100(4), http://onlinelibrary.wiley.com/ doi/10.1002/csr.132/epdf, 10.10.2015.

9. Davis K.: Can Business Afford to Ignore Social Responsibilities? "California Management Review", No. 2, 1960.

10. Dichtl E.: Grundidee, Entwicklungsepochen und heutige wirtschaftliche Bedeutung des Markenartikels, [in:] Markenartikel heute - Marke, Markt und Marketing. Gabler Verlag, Wiesbaden 1978.

11. Du S., Bhattacharya C., Sen S.: Maximizing Business Returns to Corporate Social Responsibility (CSR): The Role of CSR Communication. "International Journal of Management Reviews", 2010.

12. Ellen P.S., Webb J., Mohr L.A.: Building Corporate Associations: Consumer Attributions for Corporate Socially Responsible Programs. "Journal of the Academy of Marketing Science", No. 34(2), 2006.

13. Garriga E., Mele D.: Corporate Social Responsibility Theories: Mapping the Territory. "Journal of Business Ethics", No. 53, 2004.

14. Green Paper. Promoting The European framework for the Corporate Social Responsibility, European Commission.

15. Groza M., Pronschinske M., Walker M.: Perceived Organizational Motives and Consumer Responses to Proactive and Reactive CSR. "Journal of Business Ethics”, No. 102, 2011.

16. Haley E.: Exploring the construct of organizations as source: consumers' understanding of organizational sponsorship of advocacy advertising. "Journal of Advertising", No. 25, 1996.

17. He H., Li Y.: CSR and service brand: The mediating effect of brand identification and moderating. 2011.

18. Johnson H.L.: Business in Contemporary Society: Framework and Issues. Wadsworth, Belmont, CA 1971.

19. Kanter M.E.: From Spare Change to Real Change: The Social Sector as Beta Site for Business Innovation. "Harvard Business Review”, 1999.

20. Klein J., Dawar N.: Corporate Social Responsibility and Consumers' Attributions and Brand Evaluations in a Product-harm Crisis. „International Journal of Research in Marketing”, Vol. 21/3, 2004.

21. Lichtenstein D.R., Drumwright M.E., Braig B.M.: The Effect of Corporate Social Responsibility on Customer Donations to Corporate-Supported Nonprofits. "Journal of Marketing”, No. 68, 2004.

22. Maheshwari V. Kumar: To create a positive brand image through Corporate Social Responsibility. 2013, http://papers.ssrn.com/sol3/papers.cfm?abstract_id=2466844.

23. Maignan I.: Consumers' Perception of Corporate Social Responsibility: A Cross Cultural Perception. "Journal of Business Ethics", No. 30(1), 2001. 
24. Meffer H.T., Burmann H., Koers Ch.: Stellenwert und Gegenstand des Markenmanagement, [in:] Meffert H., Burmann H., Koers Ch. (Hrsg.): Markenmanagement. Wiesbaden 2002.

25. Mohr L.A., Harris K.E.: Do consumers expect companies be socially responsible? The impact of corporate social responsibility on buying behaviors. „The Journal of Consumers Affairs", Vol. 35, No. 1, 2001.

26. Pivato S., Misani N., Tencati A.: The impact of corporate social responsibility on consumer trust: the case of organic food. "Business Ethics: A European Review", No. 17(1), 2008.

27. Porter M.E., Kramer M.R.: The big idea: Creating shared value. "Harvard Business Review”, 2011.

28. Ramasamy B., Yeung M.: Chinese Consumers' Perception of Social Responsibility (CSR). "Journal of Business Ethics", No. 88, 2009.

29. Teraji S.: A model of corporate social performance: Social satisfaction and moral conduct. „The Journal of Socio-Economics”, No. 38, 2009.

30. Visser W.: The Age of Responsibility: CSR 2.0 and the New DNA of Business. Wiley, London 2011.

31. Vlachos P.A., Tsamakos A., Vrechopoulos A.P., Avramidis P.K.: Corporate social responsibility: attributions, loyalty, and the mediating role of trust. "Journal of the Academy of Marketing Science", Vol. 37, Iss. 2, 2009.

32. World Business Council for Sustainable Development. Corporate Social Responsibility: making good business sense. Red Letter Desig, London, UK 2000. 